\title{
A CRITIQUE OF THE MODEL PENAL CODE SENTENCING PROPOSALS
}

\author{
Wirl C. TURnBLAdH*
}

The effort of the American Law Institute in the drafting of a Model Penal Code is one that deserves the attention not only of the bench and the bar, but of those in the field of criminal correction, and, sooner or later, the leading organizations of the lay community. It is the kind of effort that is made only at rare intervals, and it may well have an impact that will last for generations. All of these factors render critical examination urgent, to ensure that the final product will reflect the best thinking available and conform with the goals of progress.

With this realization, the National Probation and Parole Association has, since the initiation of the Code project, endeavored to elicit the opinion of those in the correctional field on its various proposals, particularly those dealing with sentencing and correction. It has, through meetings and the submission of briefs, presented the distillate of this canvass to the Code Reporters, as well as to the ALI Council. Much of the material in this paper, indeed, is drawn from briefs, submitted or in preparation.

It is not difficult for people dealing with correctional administration or reform to concur on certain general principles. All could agree, for example, that punishment is necessary, but that it should serve a constructive purpose. Opinions, however, may well diverge when specific means of achieving this end are considered. It is to these matters, accordingly, that attention and energy must primarily be devoted, so that through counsel and discussion, differences may be resolved, if possible, and an accord reached that will advance correctional work and the welfare of the country.

The opinions expressed in this paper are those of the writer, but they are not his alone. They reflect, as well, the views of the Advisory Council of Judges of the NPPA, a group of leading trial and appellate court jurists drawn from all sections of the country, the Advisory Council on Parole of the NPPA, and various advisers from the field of correction who have studied the Code proposals.

I

IMPRISONMENT

A. Maximum Terms

The Code would prescribe maximum terms for felonies, to be automatically imposed, as follows: ${ }^{1}$

*A.B. 1932, LL.B. I934, Ph.D. I935, University of Minnesota. Director, National Probation and Parole Association. Formerly Probation Director and Chief of the Juvenile Division Los Angeles County Probation Department.

${ }^{1}$ Model PeNal Code $\S \S 6.06,6.07$ (Tent. Draft No. 2, r954). 
Grade of Felony

first degree second degree third degree
Maximum TermOrdinary

life imprisonment ten years

five years
Maximum TermExtended

life imprisonment ten to twenty years five to ten years

There is considerable evidence that the scale of prison terms employed in this country is too high. The number of prisoners is steadily growing not only absolutely, but also relatively to the general population. ${ }^{2}$ This has resulted in the overcrowding of prisons and a more urgent need for additional facilities; and the pressure certainly will not abate unless means are found to change existing sentencing practices. A pattern of maximum terms lower rather than higher than those now prevailing must be sought.

Experience indicates that prisoners can safely be released earlier than is generally the case, particularly if they are professionally supervised and helped while on parole. Experience further shows that many offenders now in prisons could safely have been granted probation if effective probation service had been available in the court which committed them. The scale of punishments under the proposed Code, however, conjures up a picture of the average offender as an extremely dangerous individual; it would deter judges from the use of probation, when the social need is to the contrary. What is required, instead, is a scale of punishments that will encourage the use of community correctional treatment and make parole a flexible tool, enabling earlier release at the discretion of the parole board. This would conform with the lessons experience has taught, and to this end, the Code should point.

A statement by Professor Henry Weihofen in his book, The Urge to Punish, seems appropriate to quote and consider: ${ }^{3}$

It is not only criminals who are motivated by irrational and emotional impulsions. The same is true also of lawyers and judges, butchers and bakers. And it is especially true on such a subject as punishment of criminals. This is a matter on which we are all inclined to have deep feelings. When a reprehensible crime is committed, strong emotional reactions take place in all of us. Some people will be impelled to go out at once and work off their tensions in a lynching orgy. Even the calmest, most law-abiding of us is likely to be deeply stirred. All our ingrained concepts of morality and "justice" come into play, all our ancient tribal fears of anything that threatens the security of the group. It is one of the marks of a civilized culture that it has devised legal procedures that minimize the impact of emotional reactions and strive for calm and rational disposition. But lawyers, judges and jurors are still human, and objective, rational inquiry is made difficult by the very irrationality of the human mind itself. . . . It is time we Americans realized that we have probably the most ferocious penal policy in the whole civilized world.

${ }^{2}$ Compare N.Y. Pruson Ass's, Third Report 358 (1847), and U.S. Census Office, Statisticai View of the United States, A Compendiom of the Seventa Census table ClXXIX (1850), with U.S. Bureau of Prisons, Dep't of Justice, National Prisoner Stattstics, Prisoners in State and Federal Instirutions, 1956, table I (1957). See also Rubin, Long Prison Terms and the Form of Sentence, 2 N.P.P.A.J. 377 (1956).

${ }^{3}$ Henri Weihofen, The Urge to Punish I30, I48 (1956). 
Parole boards have a considerable interest in the maximum terms prescribed. It is not sufficient to suggest that if a parole board considers a maximum term to be excessive, it can discharge the individual from parole, thus terminating the commitment altogether. There are several things that this overlooks. Most importantly, it is not the province of the parole board to exert absolute authority over the matter of the duration of a commitment, and it is not helpful to give it such authority. The judge should be equipped with a presentence investigation, just as the parole board should be equipped with a parole study, and like the parole board, he must exercise his discretion to implement the requirements of individualized treatment. If he fails to do so with respect to the maximum term, the parole board is deprived of the guidance of his judgment. Moreover, when faced with a very high maximum term, whether legislatively or judicially-fixed, the parole board, being a responsible body, accords it a measure of respect. Indeed, experience shows that the length of time during which the parole board keeps an offender institutionalized and supervised is directly related to the maximum term that has been imposed.

To avert excessively long imprisonment, therefore, two things are necessary: First, the judge must have a discretion to fix a maximum term less than that prescribed under the statute. Second, the scale of punishments must be reduced substantially below its present levels.

\section{B. Extended Terms}

The extended terms proposed under the Code purport to serve a purpose somewhat similar to that of the habitual-offender, repeated-offender, or recidivist statutes found in most jurisdictions. Their rationale is that among convicted offenders, there are those who constitute an especial danger to the community, or those who are particularly difficult to deal with in any ordinary therapeutic or custodial way; and this technique is supposed to furnish a suitable mechanism for sentencing such offenders.

If the statutes exacting heavier penalties for recidivists actually operated in this manner, they would be unobjectionable. Experience, however, shows that they do not. It is notorious that the offenders who have been committed to extended terms under these statutes have not been the most dangerous, but more typically are the underlings of the rackets, the "small fry." Almost all professional observers have concluded that these recidivist statutes have been inconsistently applied and are of little value. One commentator, for example, has said: ${ }^{4}$

It can hardly be said that the popularity of this practice was, or is, due to the theoretical possibilities of deterrence and reformation inherent in such penalties. Whatever the belief was formerly, present knowledge does not support it. Rather, revenge, and protection gained by eliminating the culprit from society, seem to be the reasons for its continued use. ... It may be justly said that in the United States the recidivist laws have never been successful.

'Brown, The Treatment of the Recidivist in the United States, 23 CAN. B. Rev. 640, 664 (1945). 
And another has written:

Evidence of the failure of the habitual offender laws has come from numerous sources during the writer's inquiries into the problem. It adds up to a conclusion that nowhere do these statutes effectively control organized criminal enterprise. They simply do not touch the problem.

Why is this so? For these reasons: The recidivist statutes play havoc with the orderly procedure of accusation, since the potential unjust penalities are avoided by the prosecutor in negotiations for pleas of guilty or in other ways. They similarly adversely affect trial procedures, involving the judge in negotiations regarding plea and sentences. ${ }^{\mathfrak{b}}$ Moreover, they prejudicially affect sound jury procedures, resulting in a variety of rules for proving the prior offenses, with a confusion of effects and purposes in giving such evidence to juries or withholding it. The mandatory aspects. of some of these statutes also deprive the courts of considerable discretion, essential to a sound penology, with respect to not only the limits of commitments, but also the use of probation. And, finally, they limit parole authorities in their discretion, because of the increase in minimum terms they prescribe. The result is a chronic "prison problem" in America, with a variety of destructive effects on the people imprisoned, on their families, and on correctional services.

The present Code proposal wisely leaves the matter of the extended term within the discretion of the judge, ${ }^{7}$ a feature that is found in a number of the existing statutes as well. To be useful rather than destructive, however, such a statute should further do or attempt to do two other things: First, it should provide a definition and the legal criteria of "dangerous offender" which actually accords with the security needs of the community. Second, it should provide for the most efficient means of detecting such a "dangerous offender," subjecting only him to the extended term, while excluding others, for whom the extended term would be excessive.

It is felt that the present Code definition and apparatus do not provide effective instruments for these purposes. Here, again, however, it should be noted, issue is taken not with the objective, but rather with the means through which its attainment is proposed. The NPPA is currently formulating an alternative "dangerous offender" code provision which, it is believed, will be an improvement over the instant proposal and which, it is hoped, the ALI will study and draw upon. Like the Code proposal, it is based on the realization that the community will be ready to accept a more moderate sentencing structure for the ordinary offender if it is confident that the dangerous offender will not be free to prey on society.

\footnotetext{
-Tappan, Habitual Offender Laws and Sentencing Practices in Relation to Organized Crime, in Organtzed Crime and Law Enforcement i13 (1952).

- These aspects of sentencing are treated more extensively elsewhere in this symposium. See Ohlin and Remington, Sentencing Structure: Its Effect Upon Systems for the Administration of Justice, supra p. 495.

${ }^{7}$ Moder PenaI Code $\$ 5.06,6.07$ and comment thereto (Tent. Draft No. 2, I954).
} 


\section{Minimum Terms}

The Code would prescribe minimum terms for felonies, as follows: ${ }^{8}$

\begin{tabular}{lll} 
Grade of Felony & \multicolumn{1}{c}{$\begin{array}{c}\text { Minimum Term- } \\
\text { Ordinary }\end{array}$} & $\begin{array}{c}\text { Minimum Term- } \\
\text { Extended }\end{array}$ \\
first degree & $\begin{array}{l}\text { not less than one nor } \\
\text { more than ten years }\end{array}$ & $\begin{array}{l}\text { not less than ten nor } \\
\text { more than twenty years }\end{array}$ \\
second degree & $\begin{array}{l}\text { not less than one nor } \\
\text { more than three years }\end{array}$ & $\begin{array}{l}\text { not less than one nor } \\
\text { more than five years }\end{array}$ \\
third degree & $\begin{array}{l}\text { not less than one nor } \\
\text { more than two years }\end{array}$ & $\begin{array}{l}\text { not less than one nor } \\
\text { more than three years }\end{array}$
\end{tabular}

One of the truly destructive elements in present-day sentencing practice is the imposition of minimum terms, especially those which, at the discretion of the sentencing judge, may (in some states) be inordinately high. It must be recognized that a high minimum term limits parole flexibility and handicaps the entire correctional process. Parole boards need the power to release the offender when his adjustment seems to them to warrant it. If the parole board does not have this power, then the commitment is obviously one of sheer punishment, depriving not only the individual, but the parole board-and, hence, the community-of the opportunity of applying what may be the most appropriate form of rehabilitation.

\section{Misderneanants}

The Code prescribes sentences for misdemeanors and petty misdemeanors, too- a definite term of not more than one year, with parole seemingly impossible.? Again, the pattern of ordinary and extended and minimum terms is used, and its only apparent justification is one of symmetry with the proposals for felony commitments, since it is hardly related to correctional treatment. There is little to recommend a form of commitment which abolishes the possibility of parole even for minor offenders serving terms up to one year. Nor is it sound to conclude that parole cannot be used for such offenders, simply because it is little used at present. On the contrary, it is necessary for leaders in the judiciary and in the correctional field to make every effort to develop proper parole procedures in this area. Experiments in local parole are, in fact, being carried forward in a number of places, and workable systems are being devised. Most judges of lower criminal courts, moreover, vigorously endorse such systems.

\section{II}

\section{Probation}

The Codè originally articulated what amounted to a presumption in favor of imprisonment and proposed a series of criteria which had to be met before probation could be granted. ${ }^{10}$ It was the opinion of the Advisory Council of Judges of

${ }^{8}$ Ibid.

${ }^{10} 7 d . \$ 7.01$.

'Id. $\$ \$ 6.08,6.09$. 
the NPPA, however, that the proposed criteria would deter rather than encourage the appropriate use of probation. Accordingly, in order to gauge the prevalent sentiment not only in the immediate matter, but also as to the use of criteria in general -for they are widely employed elsewhere in the Code-a questionnaire survey was conducted among a number of judges of criminal courts located in different parts of the country, none of whom were members of the Advisory Council.

Most of the judges who opposed the incorporation of criteria in the Code felt that they would either decrease a court's latitude in the use of probation, or not affect it at all. But these judges criticized the criteria for other effects they would have as well. A number stressed the fact that the judge ought not to be circumscribed in the exercise of his discretion by any such detailed provisions. Some observed that the criteria might encourage unnecessary litigation, in that they would tend to encourage defense counsel to attempt, in any given case, to place their clients within one of the categories in an effort to establish their right to probation. Several also pointed out that offenders would assume that they were entitled to probation as a matter of right if they could qualify under the criteria set forth, and the statute might, thus, encourage a rash of habeas corpus proceedings where probation had been denied.

The view was expressed by a number of judges, too, that even if the criteria are proper for consideration by the judge, they should not be incorporated in the Code, since this might encourage their routine, mechanical use. Moreover, it was remarked that the criteria proposed do not embrace all of the cases in which probation might be appropriate. Furthermore, some of the specific criteria were questioned. One judge declared "they do not stress the court's expectation of future reform strongly enough. They stress the past, not the future. They are negative, not positive."

In any event, Professor Wechsler, the Chief Code Reporter, and the ALI Council are redrafting the relevant provisions, taking these views into account, and the latest material appears to incline in a direction consistent with a more progressive use of probation.

\section{III}

Procedure on Sentence

\section{A. Mandatory Presentence Reports}

The Code contains a laudable proposal requiring a presentence investigation in all serious cases and in all cases affecting youth. ${ }^{11}$ This is a forward-looking step, and it merits widespread adoption. Only with a presentence investigation available can a judge confidently sentence on the basis of knowledge, rather than hunch.

\section{B. Confidentiality of Presentence Reports}

The Code provides that before imposing sentence, the court shall advise the defendant or his counsel of the factual contents and the conclusions of any presentence or psychiatric investigation and afford to the defendant an opportunity to

${ }^{11}$ Id. $\$ 7.07(\mathrm{r})$. 
controvert them. ${ }^{12}$ As is pointed out in the commentary, however, this provision is a controversial one. The NPPA's Standard Probation and Parole Act deals with this matter as follows: ${ }^{13}$

The presentence report, the preparole report, and the supervision history, obtained in the discharge of official duty by any member or employee of the board, shall be privileged and shall not be disclosed directly or indirectly to anyone other than the board, the judge, or others entitled under this act to receive such information, except that the board or court may in its discretion permit the inspection of the report or parts thereof by the defendant or prisoner or his attorney, or other person having a proper interest therein, whenever the best interest or welfare of a particular defendant or prisoner makes such action desirable or helpful.

The information-gathering function of the probation and parole service is supported by this provision, which enables the staff to assure persons providing information that it will not be routinely disclosed. This policy also supports the relationship of the probation or parole officer to persons under investigation or supervision by avoiding disclosures which might be damaging to the individual or cause recrimination. A policy of routine or mandatory disclosure would have to be interpreted to informants and might inhibit the free disclosure of information that might otherwise be forthcoming. On the other hand, since it is desirable in certain situations to disclose a report or parts of it to the defendant or prisoner or his attorney, the Standard Probation and Parole Act authorizes the court, in its discretion, to make such disclosure or permit inspection.

\section{IV}

\section{Parole}

\section{A. Separate Parole Term}

Underlying the Code provisions regarding the length of terms is a proposed division of terms-or a multiplication of terms-so that an offender faces two termsone, a term of commitment, and the other, a wholly new concept, an additional term of parole. ${ }^{14}$ That is, at the time of parole release, the term of imprisonment would come to an end and a parole term of a specified duration would commence. The minimum parole term would be at least one year or one-half of the period of time that the offender actually served in the institution, whichever were longer; the maximum parole term would be ten years or twice the period of time actually served in the institution, whichever were shorter.

At the present time, in all states, a term of commitment embraces both the term of institutionalization and the term on parole. In other words, at present, a commitment of ten years may represent five years in the institution and five years on parole. But under the Code proposal, a ten-year term of which the offender served five years would actually be a term of five years plus a possible maximum term of

\footnotetext{
${ }^{12}$ Id. $\$ 7.07(5)$.

${ }^{13}$ NPPA, Standard Probation and Parole Act $\$ 5$ (1955).

14 Model Penat Code $\$ 6.09$ A (Tent. Draft. No. 5, 1956).
} 
ten years on parole, or a total of fifteen years. In fact, it would be possible for the so-called ten-year term to become a term of ten years (perhaps less one day) in an institution plus a term of ten years on parole, or a total of twenty years for a term which was actually designated as only ten years.

Apart from lengthening the combined period of sentence, the proposed separate parole term is perhaps intended to afford a parole board a longer period of supervision than is possible at present. The extension of parole terms, however, is neither necessary nor useful, for if parole is to succeed at all, it will in most cases be in two or three years.

\section{B. Mandatory Parole}

The Code proposes that all offenders shall be released on parole, and it seeks to accomplish this, as described above, by providing that when an offender is released from an institution, whether before or upon the expiration of his term of imprisonment, a new separate term, the parole term, comes into being. The resultant universalization of parole is a sound goal, of course, but whatever possible gain might be achieved by this plan would largely be offset by the increase in the total term. It must be remembered that even under existing laws, where parole is a matter of discretion, not of right, there are jurisdictions in which sixty, seventy, eighty, and even over ninety per cent of releases are attained through parole. Moreover, under the Code proposal, not only the poor risks, but also the good ones might have their terms considerably extended, since both the minimum and maximum parole terms would be based on the amount of time served in the institution, and a parole board which might otherwise be inclined to release an individual at an early date-for example, perhaps after one year-might feel it necessary to postpone the granting of parole in order to increase the period of supervision beyond the automatic two years prescribed under the Code. Thus, a parole board could not grant an early release with a long parole period, even if this were indicated in a particular case.

The Code proposal would, moreover, foster a mechanical approach to administration. All too often, parole boards, like prisoners, become more concerned with arithmetic than with attitudes, more solicitous about calculating the term than preparing for release at the most beneficial time.

\section{Representation by Counsel at Parole Hearings}

The Code grants to a prisoner the right to consult with his own legal counsel in preparing for a hearing before the parole board. The provision was later amended to give the prisoner the right to be represented by counsel at the hearing. ${ }^{15}$ The Standard Probation and Parole Act, however, provides that "the Board shall not be required to hear oral statements or arguments by attorneys or other persons not connected with the correctional system," 16 and this position is endorsed by most of the correctional and parole administrators in the country. The following comment which appears in the Standard Probation and Parole Act, explains its provision:

${ }^{26}$ Id. $\S 305 . \operatorname{Tr}(2)$.

${ }^{10}$ NPPA, op, cit. stpra note $13, \$ 22$. 
Improper activities of paid attorneys have done much to bring parole into dispute in many states. Some attorneys solicit business from prisoners, representing that they have influence to get paroles for a fee. The representation is, unfortunately, well founded in some states. Even attorneys who are members of the legislature present cases before some parole boards in spite of the fact that in doing so they may be exerting improper influence by reason of their power to oppose appropriations and policies of the state officers who compose the parole board.

In general, it is undesirable to have attorneys or relatives and friends of the prisoners present when the parole board is interviewing him and discussing his potentialities for parole. But in order to hear the arguments and pleas of these persons, some patole boards hold special meetings at which they may appear, but at which decisions are not necessarily made. These meetings make it easier for board members to discourage such persons from attempting to interview them individually, a most undesirable practice.

\section{Criteria}

The Code declares that when the parole board deliberates, it shall order the release of a prisoner unless any one of four specified criteria exists. ${ }^{17}$ Boards of parole use many criteria and guides in arriving at their decisions, but the variety of situations and kinds of offenders are such that no simple guides, as are here proposed, are likely to be adequate or even substantially agreed upon. Furthermore, these criteria might be interpreted as creating a right to parole, inviting countless writs by prisoners whose paroles had been denied.

\section{V}

\section{Treating the Youthful Offender}

Several years ago, when Tentative Draft Number Three of the Code was first published, the field of correction, and especially of youth treatment, was alarmed at the proposals which, in effect, totally repudiated the ALI's Model Youth Correction Authority Act. This Act, promulgated in 1940, had served as an effective tool for the organization of approximately ten equivalent authorities among the states and in the federal system. It was one of the most important incentives to a surge in philosophy, legislation, administrative organization, and expansion of services relating to youth treatment. At the request of the NPPA, the ALI, in April 1956, called a meeting of youth authority leaders from many parts of the country, who affirmed to the Code Reporters and the ALI Council their belief in the youthauthority idea. But when Tentative Draft Number Seven of the Code was presented to the ALI membership in May I957, it was found to be essentially a statutory version of the proposals originally set forth in Tentative Draft Number Three. ${ }^{18}$

\section{A. Terminology}

The key term used in the Code proposal for a special part of court as well as for correctional services for youth is "young adult" or "young adult offender." It would appear, however, that the preferable term is "youth" or "youthful offender." Among

17 Model Penat Code $\$ 305.13$ (Tent. Draft. No. 5, 1956).

${ }^{18}$ Id. $\$ \$ 4.10,402.3,6.05$ (Tent. Draft No. 7, 1957); cf. id. at 2-4 (Tent. Draft No. 3, 1955). 
the existing courts for offenders, those which deal with children are universally denominated juvenile courts; the others, dealing with adults, simply criminal courts. It is evident that the instant group of offenders is between the two-above juvenilecourt age, but still minors (although there may be some control after an individual becomes twenty-one). Where intermediate courts or procedures have been established -for example, in New York and in the many jurisdictions with youth authoritiesthe term used is youth. This terminology accords with the realities of personality development, since the offenders are still in their adolescent period.

\section{B. Youth Court Organization}

The Code proposes supplemental provisions establishing a special part of court for "young adult offenders."19 Based on general principles of judicial organization, which appear applicable here, however, it would seem best that a separate part not be established by statute. Certain very important procedural and substantive matters must be provided for with respect to the court procedure and disposition in youth cases, but none of these depends on the organization of a separate part.

The establishment of separate parts, divisions, or courts for special purposes is a tendency which has had adverse effects on the efficiency and quality of not only the special courts, but the whole court structure. Experience has shown that specialized courts or parts in general do not acquire the same status or receive the same budgetary support as do the courts of general jurisdiction. The pyramiding of courts also confuses administration as well as litigants. Moreover, where special courts exist, they necessarily compete for limited services, and the burgeoning vested interests become a barrier to effective admininistration and any reform. Consolidation, the obvious need sooner or later, thus becomes an extraordinarily difficult problem. Then, too, the variety of methods of selection of judges that prevails where special courts exist increases the difficulty of attracting the best men to the bench. Special judges, in addition, tend to be out of the mainstream of the regular judiciary.

Nor are specialized courts or parts necessary to achieve the objectives contemplated for the special part for youth; they can be achieved within a general court system. If the problem is one of additional judges, this can be solved. If the problem is one of obtaining judges with a specialization in one phase of the law or another, this, too, can be remedied through special assignment within the general court system. Establishing the special functions within the general court system, moreover, has an additional advantage, in that neither constitutional nor legislative changes are needed to meet new situations. Changes can be made within the judiciary itself and its organization.

Accordingly, the NPPA has proposed that the ALI consider the plan of prescribing certain powers and procedures in the courts of general criminal jurisdiction; authorizing these courts to determine when and where a special assignment, which could be designated as a part or division, should be set up; and empowering it to

${ }^{30}$ Id. app. A (Tent. Draft No. 7, r957). 
do so. This would enable the establishment of a special part, where indicated, without the need for a statutory change. Actually, only in the larger cities is there a sufficient volume of such work to warrant the establishment of such a division or part.

\section{Procedure and Jurisdiction}

The Code proposal of a special part of court for young adult offenders does not offer any special procedures for dealing with youth. It refers to approval of places for the detention of persons awaiting proceedings, to probation and other services, and to assignment of counsel. These are not new tools, however, and do not add greatly to existing procedures and techniques. There are sources in existing law, however, offering precedents for special procedures which have, in fact, proved quite effective and appropriate for youthful offenders. The New York youthful offender procedure, for example, which has been in existence since $1943,{ }^{20}$ provides for a screening of offenders in the criminal court to determine which ones are suitable for treatment as a special noncriminal category, designated as "youthful offender." About thirty-eight per cent of eligible youth have been dealt with in this way in that state. In addition to the noncriminal disposition, this procedure features an early investigation upon which the court, with consent of the youth, determines whether youthful offender procedure shall be applied; the sealing of the indictment and the protection of records; and the usual dispositions-probation, fine, commitmentexcept that the defendant is not deemed to have been convicted of crime, and where there is a commitment, its duration is limited.

The Code proposes that in sentencing a young adult offender to the special term provided or in imposing any sentence other than one of imprisonment, the court may order that so long as he is not convicted of another felony, the judgment shall not constitute a conviction for the purposes of any disqualification or disability imposed by law upon conviction of a crime. It further proposes that when any young adult offender is unconditionally discharged from probation or parole before the expiration of the maximum term, the court may enter an order vacating the judgment of conviction. ${ }^{21}$

Although such provisions would seem to be quite progressive, they are, in fact, quite limited as compared with some existing provisions in a number of jurisdictions, and they fall short of the optimal provisions that could be proposed for youthful offenders. For one thing, they do not actually provide a noncriminal disposition; rather, they only avoid certain disqualifications which are the consequence of a conviction. All too often, however, we encounter the tragic experience of youthful offenders, many of whom are convicted of crimes which are the results of youthful impulse and not representative of a criminal pattern, youth who are headed for successful careers or respectable lives, whose future opportunities for professional work or satisfactory employment are grievously impaired, to their own detriment and

${ }^{20}$ N.Y. CRIM. CODE $\$ 913$.

${ }^{21}$ Model Penal Code $\$ 6.05$ (Tent. Draft No. 7, 1957). 
to that of the community, by the existence of the criminal conviction which inexorably follows them. This effect can be mitigated and the community, at the same time, can be amply protected by the provision that the disposition shall be deemed noncriminal, so that the youth may accurately say that he has not been convicted of a crime. Expunging the record later on comes too late.

Judge Sylvia Jaffin Singer, of the New York City Domestic Relations Court, for ten years assigned to the youth parts of the New York County courts wherein the youthful offender law was operative, writes as follows: ${ }^{22}$

The volume of cases I handled during those years ranged from r200 to r800 annually. The hope of noncriminal adjudication was in my experience a great incentive to rehabilitation in many instances. Many young people who were adjudged youthful offenders and not criminals were encouraged to try to keep their records clean. Many who adjusted themselves in the community came back to thank us for the consideration they had received and reported that their progess had been made possible by the absence of a criminal record.

To expunge the record after a youngster has borne it and been identified in the community as a criminal, provides little help to him. The proposed code bids him fly but weights his wings so he cannot get off the ground. It would prevent some of the near miracles the judges in New York County have known. I cite merely one, a youngster originally charged with armed robbery ultimately adjudged a youthful offender who is now a physician after a distinguished record in college and medical school. None of this would have been possible had he been stigmatized with a criminal record at the age of sixteen when he perpetrated his criminal act.

Under the New York plan, it should be emphasized, the determination of whether a youth shall be tried as a youthful offender is made at the outset of the proceeding. This is a desirable feature, as it puts the stamp on the proceeding at once, thereby facilitating all subsequent steps. It would be anomalous to attach a noncriminal disposition to a completely criminal proceeding. This determination also governs the applicability of a special commitment, limited to three years, which is prescribed for those who are retained for trial as youthful offenders. A recent statutory modification, enacted in $195^{6}$ but not yet in effect, would add that where the underlying act is a felony, a five-year indefinite term may be imposed. ${ }^{23}$ These terms seem practical.

\section{Organization of a Youth Authority}

As has been noted above, Tentative Draft Number Seven of the Code does what Tentative Draft Number Three proposed-it rejects the youth authority plan. It declares that an offender sixteen years of age or over but less than twenty-two years of age shall be committed to the custody of the Division of Young Adult Correction of the Department of Correction. One may agree with the present Code position that the power to sentence-that is, the power to select among probation, suspended sentence, fine, or commitment-should remain with the judge. When commitment

2atter from Judge Singer to author.

${ }^{23}$ N.Y. Unconsol. Laws $\$ 4356$ (McKinney 1957). 
is determined upon by the judge, however, it should be to a "youth authority," an autonomous administrative unit, either independent or a separate division in a state department, responsible for the whole youth correction program, including institutions, diagnostic facilities, and both state-wide leadership and assistance to communities in crime and delinquency prevention. This authority should be authorized to receive commitments of youth beyond juvenile court age only, or to receive commitments of both minors outside of juvenile court age and juvenile court commitments; and a model act for youth treatment should authorize either of these forms. Although similar advances in the correctional treatment of adults is desirable, the specialization of the youth authority is vital. It should, therefore, not be necessary to increase the age level in order to embrace a wider group of individuals in a modern youth correctional program.

The Code also sets up a Young Adult Division of the Board of Parole. ${ }^{24}$ Although such a plan has some realistic meaning for a board like the United States Board of Parole, with eight members, whose youth correction division has three members, for most boards this is not feasible. There are very few boards with more than three full-time members. A youth division of the board would, therefore, consist of the same members as the adult parole board. It should, however, rather be a separate board of three members or more, depending on the volume of work, and it should be empowered to grant a parole at any time, as is true of all the existing youth authorities.

\section{VI}

\section{ConcLusion}

A high proportion of sentences today are too long-twenty-five per cent are commitments of ten years or over. ${ }^{25}$ Such terms are inconsistent with present correctional knowledge and experience. They mislead the public as to the dangerousness of most offenders. Under the Code proposals, they would be lengthened, through the proposed maximum terms, minimum terms, parole terms, and other provisions.

Montesquieu wrote: "As freedom advances, the severity of the penal law decreases." 28 Public protection does not require and is not best served by a punitive penal code. Rather, one providing the framework for the fuller development and more effective application of correctional treatment is a better guarantee of public protection and, in the broader sense, of our freedom.

${ }^{24}$ MOder Penal Code $\$ 402.3$ (I) (Tent. Draft No. 7, 1957).

${ }^{25}$ U.S. Buread of Prisons, Dep't of Justice, National Prisoner Statistics, Prusoners Relzased from State and Federai. Institutions, 195i, table 6 (1955).

${ }^{30}$ Quoted in Charles L. Chute and Marjorie Beli, Crime, Courts, and Probation 8 (1956). 